\title{
DIALAMI TANPA MUNGKIN DIKETAHUI: SEBUAH SANGGAHAN ATAS PENAFSIRAN NOUMENA IMMANUEL KANT SEBAGAI ENTITAS METAFISIS
}

\author{
Muhammad R. Nirasma \\ Peneliti Independen
}

\begin{abstract}
Abstrak. Sistem filsafat Immanuel Kant, terutama epistemologinya, berusaha untuk menjembatani pertentangan antara rasionalisme dan empirisisme. Strategi yang diambil oleh Kant, adalah membuktikan bahwa pengetahuan manusia sudah senantiasa menyintesiskan unsur a priori dan a posteriori dari pengetahuan. Salah satu implikasi ontologis dari sistem berpikir ini adalah perceraian antara fenomena dan noumena. Yang pertama menjadi objek pengetahuan, sementara yang kedua menjadi objek etika. Noumena, sebagai entitas yang tak terjamah pengetahuan, kerap dipandang sebagai suaka bagi metafisika di dalam filsafat Kant. Tulisan ini berusaha untuk membuktikan tafsiran yang sebaliknya; bahwa noumena sama sekali bukan entitas metafisis, melainkan dunia yang sepenuhnya empiris pengalaman inderawi murni yang mendahului pengetahuan.
\end{abstract}

Kata Kunci: fenomena, Immanuel Kant, imperatif kategoris, noumena, tindakan.

\begin{abstract}
Immanuel Kant's philosophical system, especially his epistemology, seeks to bridge the conflict between rationalism and empiricism. The strategy taken by Kant was to prove that human knowledge has always synthesized a priori and a posteriori elements of knowledge. One of the ontological implications of this system of thinking is the divide between phenomenon and noumenon. The former becomes the object of knowledge, while the latter becomes the object of ethics. Noumenon, as an entity untouchable by knowledge, is often seen as a sanctuary for metaphysics in Kant's philosophy. This paper aims to demonstrate the opposite interpretation; that noumena is not a metaphysical entity at all, but a completely empirical world - pure sensible experience that precedes knowledge.
\end{abstract}

Keywords: phenomenon, Immanuel Kant, categorical imperative, noumenon, action.

Correspondence author: Muhammad R. Nirasma, m.nirasma@gmail.com 


\section{PENDAHULUAN}

Sejarah filsafat Barat dimulai dari zaman Yunani Kuno (Copleston History of Philosophy Volume I: Greece and Rome; Kenny 10), sekitar abad keempat sebelum masehi, ketika orang-orang Yunani mulai menggunakan rasionya untuk memahami gejala-gejala alam. Pada saat yang bersamaan mereka mulai meninggalkan penjelasanpenjelasan yang ditawarkan oleh mitologi. Mitologi Yunani, dengan dewa-dewinya yang antropomorfis, dianggap tidak lagi memadai untuk menjelaskan keberadaan alam semesta ini. Namun, perkembangan filsafat klasik tersebut sempat tersendat ketika Eropa memasuki Abad Pertengahan, di mana banyak pandangan menilai bahwa pada periode ini filsafat direduksi ke dalam teologi (Copleston History of Philosophy Volume Ii: Medieval Philosophy 2).

Kebangkitan filsafat di Barat, yang bersumber dari pemikiran-pemikiran Yunani dan Romawi, kembali terjadi pada masa Renaissance (Kebangkitan Kembali), yang dimulai dari fase humanistik di Italia sekitar abad ke-12 M kemudian menyebar ke belahan utara Eropa (Copleston History of Philosophy Volume Iii: Late Medieval and Renaissance Philosophy 207). Pada periode inilah para pemikir Eropa kembali menggali nilai-nilai luhur kebudayaan Yunani dan Romawi. Pada perkembangannya, muncul berbagai aliran filsafat. Dua aliran filsafat, khususnya dalam ranah epistemologi, yang telah ada sejak Yunani Kuno dan kembali berkembang semasa Renaissance hingga masa modern adalah rasionalisme dan empirisisme. Rasionalisme menitikberatkan pada peran akal budi manusia untuk memahami alam semesta dan keberadaannya sendiri (Markie 7196); sedangkan empirisisme lebih menekankan peran pengalaman inderawi untuk mengenali realitas (Alston 2421). Kedua aliran ini selalu bertentangan, hingga muncul seorang filsuf yang berusaha mendamaikan keduanya, yaitu Immanuel Kant.

Dalam salah satu karya utamanya, Kritik atas Akal Budi Murni (Inggris: Critique of Pure Reason; Jerman: Kritik der reinen Vernunft), Kant membuktikan bahwa pengetahuan manusia tidak diperoleh dari akal budi saja atau panca indera saja, melainkan merupakan gabungan dari peran keduanya (Copleston History of Philosophy Volume Vi: From French Enlightenment to Kant; Hardiman; Kant Critique of Pure Reason). Selain itu, Immanuel Kant juga merumuskan salah satu aliran besar dalam bidang etika, yaitu etika deontologis atau etika kewajiban. Etika Kant ini, sebagaimana akan kita lihat dalam pembahasan tulisan ini nantinya, tidak dapat dipisahkan dari epistemologinya. Pemikiran Immanuel Kant mempunyai pengaruh yang besar terhadap pemikir-pemikir lain yang hadir kemudian. Arti penting pemikiran Kant tidak mungkin diabaikan. Dengan sintesisnya antara rasionalisme dan empirisisme, Kant menghasilkan sebuah cara berfilsafat baru yang menjadi pijakan dalam sejarah selanjutnya (Hardiman 128).

Akan tetapi, sebagai buah pemikiran besar, filsafat Kant tidak dapat dikatakan selesai begitu saja. Bergenerasi-generasi penulis dan pemikir tetap menemukan sesuatu yang baru tatkala menilik dan mengunjungi kembali pemikiran Kant. Hal inilah yang melatarbelakangi penulis untuk membicarakan kembali, dan memproblematisasi, sebagian pemikiran Kant dalam tulisan ini. Pemikiran Kant sangat luas cakupannya, sehingga perlu dilakukan pembatasan yang jelas manakala membahasnya. Dalam tulisan ini, pembatasan tersebut ditandai oleh fokus permasalahan yang dipilih, yakni status ontologis dari noumena. 
Untuk memahami duduk perkaranya, perlu kiranya untuk mencermati terlebih dahulu bahwa Kant, ketika merumuskan epistemologinya dalam Kritik atas Akal Budi Murni, membagi realitas menjadi dua, yaitu fenomena dan noumena. Fenomena merupakan realitas yang dapat diketahui, sedangkan noumena merupakan benda pada dirinya (thing in itself; das Ding an sich) yang tidak mungkin diketahui oleh manusia. Pembagian ini seolah-olah menunjukkan kepada kita suatu dunia yang tersembunyi di balik dunia empiris, dan sifatnya metafisis belaka, yaitu noumena. Berkebalikan dengan sebagian pendapat yang cukup berkembang sebelumnya, bahwa noumena merupakan entitas metafisis, tulisan ini akan berusaha mengemukakan pemahaman lain. Bahwa alih-alih entitas metafisis, noumena justru entitas yang selalu hadir pada keseharian manusia dan "murni empiris."

Dalam rangka mendiskusikan dan membuat jelas pernyataan tesis di atas, pembahasan dalam tulisan ini akan diorganisasi ke dalam beberapa bagian. Bagian pertama, yakni paragraf-paragraf yang telah lewat, merupakan bagian pendahuluan yang berisikan uraian mengenai latar belakang, rumusan dan pembatasan masalah, serta tujuan penulisan. Bagian kedua menguraikan secara ringkas latar belakang biografis Immanuel Kant. Uraian ini sendiri akan mengilas riwayat hidup, karya-karya, dan garis besar pemikiran Kant. Bagian ketiga membicarakan kedudukan noumena dalam sistem filsafat Kant. Dalam hal ini, pembahasan akan menitikberatkan pada skema pembentukan pengetahuan dalam epistemologi Kant. Skema tersebut terdiri atas tiga tahap pengetahuan yang meliputi pengetahuan pada tahap estetik/penginderaan (aesthetics), tahap pemahaman (verstand), dan tahap penalaran (vernunft). Dengan mencermati "kronologi" dalam skema epistemologi ini, diharapkan akan dapat diidentifikasi dengan cermat dan tepat posisi noumena dalam pemikiran Kant. Bagian keempat akan mendiskusikan status ontologis noumena dan bagaimana prosedur mendekatinya.

\section{METODE}

Studi ini menggunakan kajian kepustakaan sebagai metode pengumpulan datanya. Data yang dimaksud berupa tafsiran dan hasil pembacaan para penulis maupun pemikir yang tersaji di dalam sekian banyak literatur mengenai Immanuel Kant dan sistem filsafatnya. Data tersebut kemudian dianalisis dan disajikan dalam diskusi yang metode penulisannya dapat dikategorikan sebagai metode argumentatif. Argumentasi, dalam hal ini, dapat dimaknai sebagai suatu bentuk tulisan eksposisi yang memiliki tingkat kesulitan tertentu karena disertai dengan pembuktian-pembuktian (Keraf 110). Dengan demikian, hasil dari studi ini bukan pada tempatnya untuk dinilai "benar/salah" berdasarkan konfirmasi empiris (misalnya, dengan mengontraskannya dengan hasil observasi lapangan), melainkan harus ditimbang berdasarkan koherensi bernalar yang coba disampaikannya (yakni, dengan mencermati alur bernalar dan keterkaitan satu proposisi dengan proposisi lain yang dibangunnya). 


\section{HASIL DAN PEMBAHASAN}

\section{Immanuel Kant, Kilasan Hidup dan Karya-Karya Utamanya}

Untuk memahami pemikiran seorang filsuf, tidaklah mencukupi jika tanpa mendudukkan pemikiran tersebut dalam konteks latar belakang kehidupannya. Di samping itu, juga penting bagi kita untuk mengetahui kondisi zaman ketika ia hidup, karena pemikiran seseorang selalu merupakan refleksi atas keadaan zamannya. Oleh karena itu, dalam bagian ini akan diuraikan latar belakang biografis Immanuel Kant, meliputi riwayat hidupnya secara singkat, karya-karyanya, serta pemikiranpemikirannya.

Immanuel Kant dilahirkan pada 22 April 1724 di Konigsberg, Prusia Timur, dari sebuah keluarga yang mengamalkan pietisme (Copleston History of Philosophy Volume Vi: From French Enlightenment to Kant 180). Di dalam keluarga inilah ia mendapatkan pendidikan yang ketat mengenai kerajinan, kejujuran, dan kesalehan. Pendidikan yang dilakukan oleh keluarganya sangat memengaruhi pemikiran Kant di kemudian hari, terutama di bidang etika yang menekankan kewajiban. Sepanjang hidupnya Kant tinggal di Konigsberg dan tidak pernah melancong ke luar dari kota tersebut, kecuali satu kali (Meiklejohn xii).

Kini kita mengenal masa dalam mana Kant hidup sebagai masa Pencerahan (Aufklarung). Salah satu karakteristik dari semangat zaman yang berkembang semasa Pencerahan adalah universalisme dan keyakinan yang sangat kuat di kalangan para pemikir akan sentralitas nalar dalam mendefinisikan manusia. Di berbagai bidang kehidupan muncul gagasan-gagasan yang memandang kebudayaan zaman Pencerahan sebagai ciri universal perkembangan umat manusia. Pada masa ini pula klasisisme Yunani bertemu dengan romantisisme dan sangat memengaruhi alam pikiran orangorang Eropa. Karya-karya Kant nantinya juga menggambarkan semangat zaman tersebut.

Sewaktu menuntut ilmu di Universitas Konigsberg, Kant mempelajari hampir semua mata kuliah yang tersedia waktu itu. Ia mendapatkan pengaruh rasionalisme Christian Wolff melalui Martin Knutzen, dosen yang sangat dikaguminya (Hardiman 131). Selain pemikiran Wolff, Kant juga mempelajari fisika Newtonian serta sistemsistem metafisika dan logika yang berkembang hingga masa itu. Sejak tahun 1755 hingga 1770 Kant bekerja sebagai privatdozent (dosen lepas) pada beberapa keluarga kaya. Periode ini sering dikenal sebagai periode pra-kritis Kant, di mana ia sangat dipengaruhi oleh pemikiran Leibniz dan Wolff, sebelum nantinya berjumpa dengan karya David Hume dan terbangun dari "tidur dogmatis"-nya (Copleston History of Philosophy Volume Vi: From French Enlightenment to Kant 135).

Pada tahun 1770 Immanuel Kant dikukuhkan sebagai profesor di Universitas Konigsberg, serta mulai meninggalkan sistem filsafat Wolff dan Leibniz. Kritik yang ia arahkan kepada Hume mengawali periode kritisnya yang kemudian membuahkan trilogi Kritik-nya, yaitu Kritik atas Akal Budi Murni (terbit pertama kali pada 1781), Kritik atas Akal Budi Praktis (Inggris: Critique of Practical Reason; Jerman: Kritik der praktischen Vernunft, terbit pertama kali pada 1788), dan Kritik atas Putusan (Inggris: Critique of Judgment; Jerman: Kritik der Urtheilskraft, terbit pertama kali pada 1790).

Kritik atas Akal Budi Murni menguraikan epistemologi Kant yang mengawinkan rasionalisme dan empirisisme untuk membuktikan kemungkinan pengetahuan. Karya 
ini diikuti oleh Pengantar untuk Setiap Metafisika Terkemudian (Prolegomena to Every Future Metaphysics), yang pada dasarnya merupakan penjelasan Kritik atas Akal Budi Murni dalam bahasa yang lebih mudah dipahami. Kritik atas Akal Budi Praktis merupakan karya di bidang etika yang menguraikan etika deontologis. Adapun Kritik atas Putusan memuat pandangan-pandangan Kant di bidang estetika.

Pada dasarnya, pokok-pokok pemikiran Kant yang tersaji di ketiga Kritik-nya merupakan usaha untuk menjawab tiga pertanyaan dasar, yaitu apa yang dapat saya ketahui, apa yang seharusnya saya lakukan, dan apa yang bisa saya harapkan? (Hardiman 132) Pertanyaan pertama dijawab dalam Kritik atas Akal Budi Murni. Pertanyaan kedua dijawab dalam Kritik atas Akal Budi Praktis. Adapun pertanyaan ketiga dijawab dalam Kritik atas Putusan.

Sistem filsafat Kant dapat disebut "Transendentalisme"1 karena bermaksud menguji kesahihan pengetahuan melalui asas-asas a priori yang secara inheren ada dalam diri subjek. Dia berusaha menemukan asas-asas a priori dalam rasio yang berkaitan dengan objek-objek dunia luar, yang disebut sebagai syarat-syarat kemungkinan (Hardiman). Dalam hal inilah Kant berusaha membuat sintesis antara empirisisme dan rasionalisme.

Filsafat Kant juga dapat disebut sebagai “Kritisisme” karena bermaksud menguji kemampuan rasio dan menentukan batas-batasnya sebelum menggunakan rasio itu untuk membangun suatu sistem pemikiran. Sebagaimana yang ia jelaskan dalam pengantar Kritik pertamanya, bahwa buku tersebut dimaksudkan sebagai penyelidikan kritis atas kemampuan inheren nalar - "a critical inquiry into the faculty of reason, with reference to the cognitions to which it strives to attain without the aid of experiences" (Kant Critique of Pure Reason). Lawan dari kritisisme adalah dogmatisme, yaitu suatu cara berfilsafat yang menggunakan rasio begitu saja tanpa menguji kemampuan rasio dan batas-batasnya terlebih dahulu. Oleh karena itu, dalam konteks ini, para filsuf sebelum Kant kerap disebut sebagai filsuf dogmatis. Pada tanggal 12 Februari 1804 Kant meninggal dunia dalam usia delapan puluh tahun.

\section{Kedudukan Noumena dalam Sistem Filsafat Kant}

Pada bagian ini penulis akan membahas kedudukan noumena dalam epistemologi Immanuel Kant. Di dalam Kritik atas Akal Budi Murni, Kant berusaha membuktikan bahwa ilmu pengetahuan itu mungkin. Kant juga berusaha menjawab pertanyaan apakah dan bagaimanakah metafisika itu mungkin/tidak mungkin sebagai ilmu (Kant Critique of Pure Reason). Namun, di dalam tulisan ini, proyek filosofis Immanuel Kant tersebut tidak akan diuraikan secara menyeluruh. Terutama pada bagian ini, pembahasan mengenai epistemologi Kant akan dibataskan hanya pada ketiga tahap pengetahuan. Oleh karena pembahasan inilah yang secara langsung relevan untuk mengidentifikasi kedudukan (ontologis) noumena di dalam sistem filsafat Kant. Kant membagi pengetahuan manusia ke dalam tiga tahap, yaitu tahap penginderaan (aesthetics), tahap pemahaman (verstand), dan tahap penalaran (vernunft).

\footnotetext{
${ }^{1}$ Suatu penelitian dinamakan transendental jika menyelidiki kondisi-kondisi murni dalam diri subjek pengetahuan.
} 
Pertama, akan kita diskusikan terlebih dahulu pengetahuan pada tahap penginderaan. Kant sependapat dengan para filsuf empirisisme Inggris, seperti David Hume dan John Locke, bahwa pengetahuan manusia bersumber dari pengalaman inderawi. Akan tetapi, Kant tidak setuju dengan pendapat mereka bahwa pengetahuan inderawi sepenuhnya bersifat a posteriori. ${ }^{2}$ Menurut Kant, manusia memang memiliki sensibilitas (kemampuan menginderai), dan dengan kemampuan ini, manusia menerima kesan-kesan mengenai objek di luar dirinya, sehingga muncul penampakanpenampakan objek di dalam pikiran.

Namun demikian, perlu diperhatikan bahwa penampakan objek-objek tersebut dapat dicerap dan dimengerti hanya karena sudah senantiasa diatur dalam hubunganhubungan ruang dan waktu. Menurut Kant, ruang dan waktu bukanlah entitas objektif yang secara mandiri mengada dan acuh terhadap keberadaan manusia. Ruang dan waktu justru merupakan forma (bentuk) dari penginderaan, dan merupakan bagian dari syarat-syarat kemungkinan yang secara inheren melekat pada rasio manusia. Adapun penampakan objek merupakan materi (isi) dari penginderaan. Kombinasi antara bentuk dan isi inilah yang memungkinkan adanya pengetahuan pada tahap penginderaan. Dengan demikian, penginderaan tidak bersifat a posteriori sepenuhnya, melainkan juga a priori. ${ }^{3}$

Selanjutnya, pengetahuan awal yang diperoleh pada tahap penginderaan akan diolah lebih lanjut pada tahap pemahaman. Pada tahap ini, pengetahuan inderawi dari tahap penginderaan diproses dengan dua belas kategori yang dimiliki rasio. Kedua belas kategori itu sendiri oleh Kant digolongkan ke dalam empat kategori besar, yaitu kuantitas, kualitas, relasi, dan modalitas. ${ }^{4}$ Pengetahuan inderawi yang telah dikenai kategori-kategori rasio ini kemudian menghasilkan putusan-putusan berupa proposisi yang sesuai dengan masing-masing kategori.

Tahap terakhir merupakan tahap penalaran. Pada tahap ketiga dari proses pengetahuan manusia ini, putusan-putusan yang telah dihasilkan pada tahap pemahaman diolah lebih lanjut oleh nalar/rasio. Di sini rasio bekerja secara silogistis, yaitu dengan membuat kesimpulan berdasarkan putusan-putusan yang telah dirumuskan. Terdapat tiga macam kesimpulan yang mungkin, yaitu kesimpulan kategoris, hipotetis, dan disjungtif (Kant Critique of Pure Reason 226). Ketiganya berkaitan erat dengan tiga kategori rasio, yaitu masing-masing dengan substansi, kausalitas, dan komunitas (Hardiman 143).

Untuk mengorganisasi proses ini, nalar menggunakan ide-ide transendental sebagai pedomannya. Ide-ide transendental, tidak seperti pengetahuan inderawi maupun kedua belas kategori, tidak lagi memperluas pengetahuan kita, melainkan hanya berfungsi mengatur (regulatif) putusan-putusan ke dalam argumentasi. Atau dengan kata lain, ide-ide transendental memungkinkan terwujudnya koherensi di antara proposisi-proposisi yang telah dihasilkan, sehingga terbentuk suatu sistem

\footnotetext{
2 Pengetahuan yang didasarkan pada pengalaman dan pengamatan inderawi semata.

${ }^{3}$ Pengetahuan yang didasarkan pada rasio semata.

${ }^{4}$ Kategori kuantitas meliputi unitas, pluralitas, dan totalitas. Kategori kualitas meliputi realitas, negasi, dan limitasi. Kategori relasi meliputi substansi, kausalitas, dan komunitas. Kategori modalitas meliputi kemungkinan-kemustahilan, eksistensi-noneksistensi, dan keniscayaan-kontingensi.
} 
berpikir yang dapat menjelaskan dunia sebagai sesuatu yang masuk akal/rasionalinilah yang kemudian kita sebut sebagai ilmu pengetahuan (science).

Kant mengidentifikasi tiga macam ide transendental atau postulat (dalil) dari rasio, yaitu ide jiwa, ide dunia, dan ide Allah - “Thus pure reason presents us with the idea of a transcendental doctrine of the soul (psychologia rationalis), of a transcendental science of the world (cosmologia rationalis), and finally of a transcendental doctrine of God (theologia transcendentalis)" (Kant Critique of Pure Reason 233). Ketiga ide ini melampaui batasan-batasan segala pengalaman, sehingga tidak mungkin diidentifikasi secara memadai dengan merujukkannya pada objek konkret apa pun, sebagaimana yang dijelaskan oleh Kant, "they are transcendent, and overstep the limits of all experience, in which, consequently, no object can ever be presented that would be perfectly adequate to a transcendental idea" (Kant Critique of Pure Reason 225). Dengan fungsi regulatifnya, ide-ide transendental menjadi pedoman bagi rasio manusia yang selalu berusaha menuju kesatuan pengetahuan yang semakin luas dan luas-rasio selalu berusaha menuju pengetahuan yang universal.

Skema epistemologis di atas membuahkan beberapa implikasi. Salah satu implikasi yang juga menjadi fokus diskusi kita di dalam tulisan ini adalah pembagian realitas menjadi dua kategori ontologis: fenomena dan noumena. Fenomena merupakan realitas yang dapat diketahui; hadir sebagai hasil pengorganisasian penampakanpenampakan objektif oleh kemampuan inheren yang dimiliki akal budi (faculty of reason). Dengan demikian, fenomena sebenarnya bukan sekadar realitas yang berada di dalam cakupan pengetahuan manusia, tetapi sekaligus hasil dari aktivitas berpengetahuan itu sendiri. Ketiga tahap pengetahuan, sebagaimana telah dijelaskan di atas, berada di ranah fenomena. Adapun noumena adalah wilayah di luar ketiga tahap pengetahuan itu; bahkan dapat dikatakan primordial, karena "mendahului" pengetahuan.

Noumena dan fenomena merupakan penamaan yang berbeda atas satu dunia yang sama, yaitu dunia yang ditinggali manusia. Pembedaan keduanya terjadi karena kapasitas sekaligus limitasi nalar sehingga, dalam konteks keberadaan manusia, menimbulkan pula pembedaan antara mengalami dan mengetahui. Dengan demikian, manusia mengada di dunia dan mengakses dunia itu sendiri dari dua pendekatan, yaitu dengan mendudukkannya sebagai fenomena dan sebagai noumena. Dunia dipahami sebagai fenomena ketika manusia menggunakan akal budinya untuk mengetahui dan menjelaskan dunia tersebut; dan dipahami sebagai noumena sebagaimana manusia mengalami dan berada di dalamnya.

Sebelumnya penulis katakan bahwa noumena mendahului fenomena, selain karena posisinya yang sudah ada sebelum pengetahuan, juga karena pada kenyataannya manusia - sebagai satu-satunya makhluk rasional yang kita ketahuisudah senantiasa mengada di dunia dan harus bertindak di dalamnya, bahkan sebelum dapat memahami dan menjelaskan dunia itu sendiri. Oleh karena itu, cara utama - atau bahkan cara satu-satunya - mengakses noumena adalah dengan bertindak; dan, jika kita ikuti alur bernalar Kant, bukan melalui tindakan belaka, melainkan tindakan moral.

\section{Tindakan Moral sebagai Prosedur untuk Mengakses Noumena}

Pada bagian ini penulis akan mendiskusikan pemikiran Immanuel Kant tentang etika. Ini penting, karena bagi Kant tindakan moral memfasilitasi pendekatan kita dalam mengakses noumena. Kant membedakan antara akal budi praktis dengan akal budi 
murni. Jika akal budi murni bertujuan untuk memperluas pengetahuan manusia, maka akal budi praktis mengarahkan manusia dalam bertindak. Akal budi ini memiliki karakteristik yang berbeda dari akal budi murni yang telah kita diskusikan pada bagian sebelumnya. Akal budi praktis dibahas oleh Kant di dalam pemikirannya di bidang etika, terutama dalam Kritik atas Akal Budi Praktis.

Etika yang digagas oleh Kant disebut etika deontologis karena menitikberatkan pada kewajiban (bahasa Yunani deon berarti kewajiban). Menurut pandangan ini, baiktidaknya suatu tindakan secara moral tidak dinilai berdasarkan tujuan dan akibat-akibat yang ditimbulkannya, melainkan berdasarkan tindakan itu sendiri. Dengan kata lain, suatu tindakan hendaknya dilakukan tidak untuk memperoleh sesuatu yang lain. Menurut Kant, hanya ada satu hal yang baik secara mutlak, yaitu "kehendak baik" kehendak yang baik pada dirinya, tidak tergantung pada yang lain (Hardiman 145). Hal ini mewujud di dalam kewajiban, karena manusia melaksanakan kewajiban tanpa pamrih, melakukannya tidak untuk sesuatu yang lain. Kant menghubungkan kewajiban dengan hukum, yaitu hukum an sich yang sifatnya universal dan tidak mengenal pengecualian. Bertindak demi kewajiban adalah bertindak dengan mengacu pada hukum tersebut (Hardiman 146).

Jika tindakan moral dilakukan tidak untuk memperoleh atau menghasilkan sesuatu yang lain dari tindakan itu sendiri, maka apakah yang menjadi dorongan bagi tindakan moral? Bukankah tindakan manusia berbeda dari perilaku binatang karena ia senantiasa diliputi motivasi, maksud, dan tujuan? Untuk membuat jelas persoalan ini, kita perlu menilik konsepsi Kant mengenai "maksim." Pada maksim inilah kita dapat meletakkan nilai moral dari suatu tindakan.

Kita perlu membedakan terlebih dahulu antara maksim dengan asas-asas. Maksim merupakan prinsip-prinsip subjektif kehendak, sementara asas-asas merupakan prinsip-prinsip moral yang terstruktur secara objektif di dalam akal budi praktis setiap makhluk rasional (Hardiman 146). Bertindak atas dasar asas-asas berarti bertindak dengan mengikatkan diri pada sesuatu yang objektif, sementara bertindak atas dasar maksim berarti merengkuh kebebasan yang dimiliki oleh diri, sekalipun kedua tindakan tersebut mengambil bentuk atau ekspresi yang sama ketika diamati oleh orang ketiga. Tindakan moral terjadi ketika maksim sesuai dengan asas-asas, yaitu ketika seseorang melaksanakan kewajibannya dengan suka rela. Dalam hal ini, manusia memiliki kebebasan dalam menentukan tindakannya. Tanpa kebebasan tidak akan ada tindakan moral, karena manusia hanya akan melakukan sesuatu tanpa kesadaran atau di bawah paksaan.

Sebagai ilustrasi, katakanlah terdapat dua orang, X dan $Y$, yang sama-sama melakukan tindakan moral $\mathrm{M}$. Keduanya melakukan $\mathrm{M}$ karena merasa tindakan tersebut memang harus ditunaikan. Dari sudut pandang pengamat, tindakan yang dilakukan keduanya tidak ada beda. Namun, dari sudut pandang subjektif $X$ dan $Y$, ternyata ada perbedaan. Ketika melakukan tindakan $\mathrm{M}$, harus bagi $\mathrm{X}$ berarti bertindak sesuai dengan asas-asas; ia melakukannya karena memang itulah yang dituntut oleh asas-asas yang ia ketahui, dan dengan demikian, ia memosisikan dirinya tanpa pilihan tidak bisa tidak, ia harus melakukannya. Adapun bagi $Y$, harus di sini berarti "butuh;" ia melakukan $\mathrm{M}$ karena tindakan itulah yang sesuai dengan kehendaknya, dan dengan demikian, dengan bertindak $\mathrm{M}$ ia menunaikan kebebasannya.

Ilustrasi di atas juga menggambarkan perlunya membedakan antara tindakan yang sesuai dengan kewajiban dengan tindakan yang dilakukan demi kewajiban 


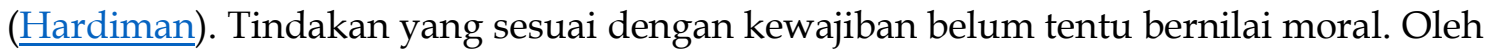
karena tindakan ini memiliki kemungkinan untuk dilakukan berdasarkan keterpaksaan, maupun demi suatu hasil tertentu. Dalam ilustrasi di atas, terlihat pada kasus X. Tindakan seperti ini disebut sebagai legalitas (Kant Critique of Practical Reason).

Berbeda dengan legalitas, tindakan yang dilakukan demi kewajiban sudah barang tentu memiliki nilai moral. Oleh karena tindakan itu dilakukan berdasarkan kesadaran dan kehendak baik, tanpa mengharapkan hasil apa pun. Dalam ilustrasi di atas, terlihat pada kasus Y. Dalam konteks sosial atau relasional, moralitas harus dibangun berdasarkan kesadaran bahwa manusia merupakan tujuan pada dirinya. Seseorang tidak boleh memperlakukan orang lain sebagai sarana belaka untuk mencapai tujuan tertentu. Manusia bukanlah sarana, melainkan tujuan an sich (Hardiman 149).

Lantas, apakah menunaikan kebebasan-bertindak sekehendak diri-sertamerta baik? Untuk menjawab pertanyaan ini, kita dapat menilik pada identifikasi Kant akan adanya dua kategori maksim, yaitu maksim empiris (material) dan maksim a priori (formal) (Kant Critique of Practical Reason 26). Maksim empiris mengacu pada hasrat inderawi dan hasil tindakan, sedangkan maksim a priori sama dan sebangun dengan hukum universal. Oleh karena itu, hanya maksim a priori yang memiliki nilai moral dalam kerangka pandang etika deontologis.

Sejalan dengan pembedaan kedua kategori maksim di atas, rumusan tindakan juga dapat dibedakan ke dalam dua macam imperatif. Tindakan moral terumuskan di dalam imperatif kategoris. ${ }^{5}$ Imperatif ini memerintahkan sesuatu bukan untuk mencapai tujuan tertentu, melainkan karena perintah itu baik pada dirinya (Hardiman 148). Imperatif kategoris berbeda dari imperatif hipotetis yang memerintahkan suatu tindakan demi mencapai hasil tertentu. Dalam hal imperatif hipotetis, suatu tindakan akan dilaksanakan dengan syarat-syarat tertentu - "Imperatives themselves, however, when they are conditional (i.e. do not determine the will simply as will, but only in respect to a desired effect, that is, when they are hypothetical imperatives), are practical precepts, but not laws" (Kant Critique of Practical Reason 18).

Sejalan dengan pemahaman di atas - sekali lagi dapat ditegaskan-bertindak moral, yakni mengaktualisasikan imperatif kategoris, berarti membebaskan diri bukan hanya dari determinasi struktur objektif yang memaksa, tetapi juga dari determinasi kondisi-kondisi yang mengaburkan pilihan etis, seperti hasrat. Dalam hal ini, melalui tindakan moral manusia mengalami kebebasannya. Dengan akal budi murni manusia dapat mengidentifikasi dan menjelaskan kebebasan. Namun hanya dengan akal budi praktis dalam tindakan moral, manusia dapat mengalaminya-mengakses secara langsung kebebasan itu sendiri, dan dengan demikian, sekaligus mengakses noumena.

\section{Noumena sebagai Pengalaman Spontan Makhluk Moral}

Pembedaan antara noumena dan fenomena merupakan konsekuensi logis dari epistemologi yang dibangun oleh Immanuel Kant. Kant berusaha merumuskan subjek pengetahuan yang memiliki sifat transendental, memiliki kapasitas inheren yang tidak

\footnotetext{
${ }^{5}$ Imperatif berbeda dari perintah. Perintah adalah asas objektif yang mengharuskan kehendak subjektif, sedangkan imperatif merupakan bentuk putusan dari perintah.
} 
terpengaruh oleh kontingensi-kontingensi dunia luar, sebagaimana terlihat jelas dari konseptualisasinya akan ruang-waktu dan dua belas kategori rasio.

Dalam epistemologi Kant, kedudukan noumena berada di luar ketiga tahap pengetahuan manusia. Jika mengacu pada kronologi dari proses kita berpengetahuan, maka bisa dikatakan bahwa noumena mendahului tahap penginderaan, dan dengan demikian, mendahului semua pengetahuan. Sekilas, pandangan ini memberikan kesan akan adanya dua dunia yang secara ontologis terpisah. Seolah-olah, ketika kita memasuki tahap penginderaan, kita telah beralih sepenuhnya dari noumena kepada fenomena. Pembedaan noumena-fenomena inilah yang sering kali menyebabkan sebagian penulis dan pemikir setelahnya beranggapan bahwa Kant masih menyisakan ruang bagi metafisika. Padahal, Kant sendiri menolak kemungkinan metafisika sebagai ilmu pengetahuan (Hardiman 144).

Pandangan ini, penulis berargumen, tidaklah tepat karena pada kenyataannya noumena tidak pernah berhenti hadir - kita tetap berada di dalamnya, sekalipun tidak mengenalinya sebagai objek pengetahuan kita. Dengan kata lain, ketika akal budi membangun pengetahuan mengenai dunia, kita tetap berada di dalam noumena dan fenomena sekaligus.

Metafisika berasal dari bahasa Yunani ta meta ta physika yang berarti yang melatarbelakangi dunia fisik (Hardiman 32; Ohoitimur). Hal ini berarti bahwa metafisika mempelajari hal-hal yang berada di balik dunia yang tampak secara inderawi. Mengacu pada pengertian tersebut, maka hal-hal yang bersifat metafisis dapat dipahami sebagai hal-hal yang tidak tertangkap oleh panca indera, sehingga tidak dapat diakses dengan pengalaman-pengalaman yang menubuh-Kant sendiri mencirikan metafisika murni sebagai spekulasi rasio (Kant Critique of Pure Reason). Noumena bukanlah konsep yang serta-merta metafisis - simpulan ini merupakan konsekuensi logis dari penalaran yang terbangun dalam sistem filsafat Kant, khususnya terkait epistemologi dan etika yang telah kita diskusikan.

Meskipun pengetahuan manusia tidak meliputi noumena, tetapi mengadanya manusia sudah senantiasa di dalam noumena. Hanya saja, tindakan moral memungkinkan manusia mengaksesnya secara langsung, sementara pengetahuan membuatnya luput karena hadirnya fenomena sebagai tabir. Jika kita cermati kembali, justru dapat dikatakan bahwa noumena merupakan dunia yang murni empirisnoumena adalah ranahnya tindakan yang sepenuhnya menubuh, sementara fenomena mengodekannya dalam pengaturan forma ruang-waktu dan kategori-kategori rasio.

Pembacaan demikian tentu menimbulkan pertanyaan, apakah ketika melakukan tindakan moral, manusia bergerak otomatis dan tanpa sadar? Jawaban singkatnya: tidak. Pada diskusi sebelumnya tentang etika, sudah terjelaskan bahwa manusia melakukan tindakan moral atas dasar kehendak baik, mengikuti maksim dalam dirinya, dan dengan tindakan itu mengaktualisasikan imperatif kategoris yang sesuai dengan maksim tersebut. Hal ini hanya berarti satu hal, bahwa tindakan moral dapat dikatakan otomatis atau serta-merta, bukan karena ketidaksadaran, melainkan karena tindakan itu merupakan aktualisasi kehendak yang menubuh, ekspresi dari kedirian seseorang.

Seseorang yang melakukan tindakan moral tidak merumuskan tindakan yang akan dilakukannya secara panjang lebar. Ia tidak menyusun pengetahuan terlebih dahulu mengenai tindakan tersebut. Juga tidak mendahuluinya dengan pertimbanganpertimbangan menyoal implikasi dan hasil yang akan dicapai. Kedirian orang tersebut mendorongnya untuk bertindak begitu saja. Oleh karena itu, tindakan moral yang 
teraktualisasikan tidak berada dalam ranah pengetahuan, dan bersifat spontan. Ini berarti, dengan melakukan tindakan moral, manusia telah menggunakan kebebasannya.

Secara empiris, manusia selalu berada dalam keadaan kini dan di sini. Masa lalu dan masa depan merupakan rumusan akal budi mengenai sesuatu yang "telah" terjadi dan sesuatu yang diharapkan "akan" terjadi. Pengetahuan manusia selalu membicarakan sesuatu yang telah terjadi, meskipun hal itu "baru saja" terjadi. Di samping itu, pengetahuan manusia juga berusaha merumuskan prediksi-prediksi tentang apa yang akan atau mungkin terjadi berdasarkan hukum kausalitas. Dengan demikian, pengetahuan manusia tidak pernah bisa merumuskan kini dan di sini, yang merupakan keadaan yang sebenarnya dari keberadaan manusia. Begitu dirumuskan, maka pengalaman kita menjadi sesuatu yang telah lewat. Dalam konteks ini, tindakan moral membawa manusia pada noumena karena secara langsung dan utuh menempatkan kita dalam kini-di sini kita. Maka jelaslah bahwa noumena bukanlah konsep abstrak yang terlepas dari cerapan panca indera, bukan pula entitas metafisis yang harus dispekulasikan oleh nalar, melainkan kondisi "empiris murni." Di satu sisi, manusia berada dalam noumena secara korporeal, dan di sisi lain, mengaksesnya secara pragmatis, yakni dengan secara bebas mengambil keputusan dan melakukan tindakantindakan yang akan menentukan bakal menjadi makhluk macam apa dirinya - atau dengan kata lain, tindakan moral. Sebagaimana yang Kant jelaskan, bahwa "pragmatic knowledge of man aims at what man makes, can, or should make of himself as a freely acting being" (Kant Anthropology from a Pragmatic Point of View 3). Hanya dalam kerangka pragmatis inilah, dan bukan kerangka metafisis, kita dapat secara tepat mendudukkan noumena di dalam sistem filsafat Kant, mengingat konsep noumena itu sendiri merupakan bagian integral dari keseluruhan teori Kant tentang pengalaman (Copleston History of Philosophy Volume Vi: From French Enlightenment to Kant 269).

\section{SIMPULAN}

Sebagaimana telah didiskusikan dalam tulisan ini, pembedaan antara noumena dan fenomena merupakan konsekuensi logis dari epistemologi Immanuel Kant. Namun demikian, tidak dapat dimungkiri bahwa pembedaan ini bukan sekadar pembedaan di aras pengetahuan, melainkan di aras keberadaan, sehingga perkara yang asalnya epistemologis justru melahirkan problematisasi ontologis. Lantas, upaya memahami relasi noumena-fenomena pun akan senantiasa berkecenderungan untuk bolak-balik antara kedua sistematika filsafat tersebut. Dalam hal inilah, kedisiplinan dalam bernalar benar-benar dibutuhkan untuk dapat terhindar dari simpulan-simpulan reduksionis dalam mengidentifikasi dan mendudukkan noumena. Penulis telah berikhtiar untuk memelihara disiplin tersebut pada sepanjang tulisan ringkas dan bersahaja ini-mudahmudahan ikhtiarnya terpenuhi.

\section{DAFTAR PUSTAKA}

Alston, William P. "Empiricism." Routledge Encyclopedia of Philosophy 10v, edited by Edward Craig, Routledge, 1998, pp. 2421-2425. 
87 | Human Narratives Vol.1, No.2, Maret 2020, pp. 76-87

Copleston, Frederick. History of Philosophy Volume I: Greece and Rome. Doubleday, 1993.

---. History of Philosophy Volume Ii: Medieval Philosophy. Doubleday, 1993.

---. History of Philosophy Volume Iii: Late Medieval and Renaissance Philosophy. Doubleday, 1993.

---. History of Philosophy Volume Vi: From French Enlightenment to Kant. Doubleday, 1993.

Hardiman, F. Budi. Filsafat Modern: Dari Machiavelli Sampai Nietzsche. Gramedia Pustaka Utama, 2007.

Kant, Immanuel. Anthropology from a Pragmatic Point of View. translated by V. L. Dowdell, Southern Illinois University Press, 1996.

---. Critique of Practical Reason. translated by T. K. Abbott, Dover Publications, 2004.

---. Critique of Pure Reason. translated by John Miller Dow Meiklejohn, Henry G. Bohn, 1855.

Kenny, Anthony. A New History of Western Philosophy. Oxford University Press, 2010.

Keraf, Gorys. Komposisi: Sebuah Pengantar Kemahiran Bahasa. Nusa Indah, 1994.

Markie, Peter J. "Rationalism." Routledge Encyclopedia of Philosophy edited by Edward Craig, Routledge, 1998, pp. 7196-7201.

Meiklejohn, John Miller Dow. "Translator's Preface." Critique of Pure Reason edited by Immanuel Kant, Henry G. Bohn, 1855, pp. xi-xv.

Ohoitimur, Johanis. Metafisika Sebagai Hermeneutika. Obor, 2006. 